\title{
Major problems with paediatric bed usage statistics?
}

\author{
R MacFaul, R Long
}

\begin{abstract}
This study was carried out on the way in which children's beds were used by the specialty of paediatrics in a district general hospital. Five differing ways were found of interpreting the present Department of Health guidelines on health services information (Körner recommendations). These gave bed occupancy figures varying between $73 \%$ and $106 \%$; throughput figures varying between 23.8 and 34.7 discharges per bed; and turnover interval varying between -0.17 and $1 \cdot 1$ days for the same group of paediatric admissions. For comparisons of efficiency and costs between hospitals, which are based upon bed utilisation statistics, it is essential that there is standardisation of method of analysis.
\end{abstract}

Analysis of bed usage is increasingly being used to assess the efficiency of use of resources. Comparison between districts may be used by managers to identify inefficiency or alternatively, overpressed services. There are particular constraints applying to the admissions of children: that is, children under 16 should not be admitted to adult wards and a high proportion of admissions into paediatric medical care and general surgical and orthopaedic care are acute and thereby uncontrolled. Children's beds tend to be used by a number of specialties treating children, including paediatric medicine. There needs to be a percentage occupancy of children's beds that is low enough to cater for peak usage (to avoid inability to admit an acutely ill child or the need to 'sleep out' the child on an inappropriate ward) and yet high enough to permit optimal use of resources.
In 1984, a Department of Health and Social Security (DHSS) health building note states 'Para 1.13: The provision and use of beds for children vary widely among health authorities. The latest regional figures available suggest a range from 0.6 to 1.4 occupied beds per 1000 population under age 1 , with only three regions having more than 1.0 per 1000 . With current clinical practice, it is considered that an occupancy rate of $75 \%$ is the optimum to allow for flexibility in acute cases. This would indicate provision of between 0.9 and $1 \cdot 1$ beds per 1000 population under age 16 , excluding mentally handicapped children and special care baby cots.' ${ }^{1}$ (Also excluded from this figure would appear to be those children with infectious disease.) Before attempting therefore to identify what an ideal occupancy might be, it is important to ensure that analysis of bed usage is standardised within a district and preferably between districts so that useful comparisons may be made. This study has been conducted to determine whether this analysis is practical in a district general hospital children's unit, taking note of the new ways of analysing bed usage recommended by the Körner report. ${ }^{2}$

\section{Methods}

(A) WARD CHARACTERISTICS (TABLES 1 AND 2)

The two wards studied were A and B wards at Pinderfields Hospital.

(i) A ward has 20 beds and nominally caters for children being admitted under the general and urological surgeons and orthopaedic surgeons. Because of the nature of the accommodation, however, children admitted as paediatric medical cases aged over 10 years are preferably admitted there also. Additionally
Department of Paediatrics, Pinderfields General Hospital, Wakefield R MacFaul

District Information Services, Wakefield Health Authority R Long

Correspondence to:

Dr R MacFaul,

Department of Paediatrics, Pinderfields General Hospital, Aberford Road, Wakefield Aberford Road, Wakefield,

Accepted 19 October 1990
Table 1 Bed usage at Pinderfields Hospital over a nine month period. Numbers are bed days/month

\begin{tabular}{|c|c|c|c|c|c|c|c|c|c|}
\hline $\begin{array}{l}A \text { ward (nominally } 11 \text { surgical, } \\
2 \text { urology, } 7 \text { orthopaedic beds) }\end{array}$ & $\begin{array}{l}\text { Fune } \\
1989\end{array}$ & $\begin{array}{l}\text { May } \\
1989\end{array}$ & $\begin{array}{l}\text { April } \\
1989\end{array}$ & $\begin{array}{l}\text { March } \\
1989\end{array}$ & $\begin{array}{l}\text { February } \\
1989\end{array}$ & $\begin{array}{l}\text { Fanuary } \\
1989\end{array}$ & $\begin{array}{l}\text { December } \\
1988\end{array}$ & $\begin{array}{l}\text { November } \\
1988\end{array}$ & $\begin{array}{l}\text { October } \\
1988\end{array}$ \\
\hline $\begin{array}{l}\text { Paediatric } \\
\text { Non-paediatric } \\
\text { Total No occupied bed days } \\
\text { Total No available bed days } \\
\text { Bed occupancy } \\
\text { No of paediatric bed days } \\
\text { No of non-paediatric bed days }\end{array}$ & $\begin{array}{c}92 \\
179 \\
2958 \\
5460 \\
54 \% \\
949 \\
200\end{array}$ & $\begin{array}{r}92 \\
238 \\
\\
(32 \% \text { o } \\
(68 \% \text { o }\end{array}$ & $\begin{array}{l}\text { occupied bed } \\
\text { occupied bed }\end{array}$ & $\begin{array}{l}\text { days, } \\
\text { days, }\end{array}$ & $\begin{array}{l}17 \% \text { available } \\
37 \% \text { available }\end{array}$ & $\begin{array}{l}75 \\
220 \\
\text { bed days) } \\
\text { bed days) }\end{array}$ & $\begin{array}{l}155 \\
188\end{array}$ & $\begin{array}{l}110 \\
204\end{array}$ & $\begin{array}{l}137 \\
200\end{array}$ \\
\hline $\begin{array}{l}B \text { ward (nominally } \\
19 \text { paediatric beds) }\end{array}$ & $\begin{array}{l}\text { June } \\
1989\end{array}$ & $\begin{array}{l}\text { May } \\
1989\end{array}$ & $\begin{array}{l}\text { April } \\
1989\end{array}$ & $\begin{array}{l}\text { March } \\
1989\end{array}$ & $\begin{array}{l}\text { February } \\
1989\end{array}$ & $\begin{array}{l}\text { January } \\
1989\end{array}$ & $\begin{array}{l}\text { December } \\
1988\end{array}$ & $\begin{array}{l}\text { November } \\
1988\end{array}$ & $\begin{array}{l}\text { October } \\
1988\end{array}$ \\
\hline $\begin{array}{l}\text { Paediatric } \\
\text { Non-paediatric } \\
\text { Total No occupied bed days } \\
\text { Total No available bed days } \\
\text { Bed occupancy } \\
\text { No of paediatric bed days } \\
\text { No of non-paediatric bed days }\end{array}$ & $\begin{array}{r}311 \\
55 \\
3594 \\
5187 \\
69 \% \\
3074 \\
520\end{array}$ & 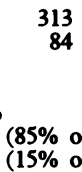 & $\begin{array}{l}\text { occupied bed } \\
\text { occupied bed }\end{array}$ & $\begin{array}{l}\text { days, } \\
\text { days, }\end{array}$ & $\begin{array}{l}59 \% \text { available } \\
10 \% \text { available }\end{array}$ & $\begin{array}{l}\text { bed days) } \\
\text { bed days) }\end{array}$ & $\begin{array}{r}360 \\
84\end{array}$ & $\begin{array}{r}355 \\
88\end{array}$ & $\begin{array}{l}349 \\
103\end{array}$ \\
\hline
\end{tabular}


Table 2 Bed usage in $A$ ward

\begin{tabular}{|c|c|c|c|c|c|c|c|c|c|}
\hline Speciality & $\begin{array}{l}\text { Fune } \\
1989\end{array}$ & $\begin{array}{l}\text { May } \\
1989\end{array}$ & $\begin{array}{c}\text { April } \\
1989\end{array}$ & $\begin{array}{l}\text { March } \\
1989\end{array}$ & $\begin{array}{l}\text { February } \\
1989\end{array}$ & $\begin{array}{l}\text { January } \\
.1989\end{array}$ & $\begin{array}{l}\text { December } \\
1988\end{array}$ & $\begin{array}{l}\text { November } \\
1988\end{array}$ & $\begin{array}{l}\text { October } \\
1988\end{array}$ \\
\hline $\begin{array}{l}\text { Dermatology } \\
\text { General medicine } \\
\text { Neurology } \\
\text { Neurosurgery } \\
\text { Orthopaedics } \\
\text { Paediatrics } \\
\text { Plastic surgery } \\
\text { General surgery } \\
\text { Urology } \\
\text { Oral } \\
\text { Ophthalmology }\end{array}$ & $\begin{array}{r}16 \\
8 \\
-11 \\
96 \\
92 \\
-41 \\
7 \\
-\end{array}$ & $\begin{array}{r}- \\
-2 \\
12 \\
148 \\
92 \\
1 \\
69 \\
6 \\
-\end{array}$ & $\begin{array}{l}-9 \\
- \\
23 \\
153 \\
98 \\
-50 \\
5 \\
2 \\
-\end{array}$ & $\begin{array}{r}- \\
\overline{1} \\
31 \\
159 \\
121 \\
2 \\
40 \\
3 \\
-3\end{array}$ & $\begin{array}{r}13 \\
1 \\
1 \\
17 \\
180 \\
69 \\
1 \\
73 \\
14 \\
-\end{array}$ & $\begin{array}{r}2 \\
5 \\
-13 \\
116 \\
75 \\
1 \\
80 \\
3 \\
-\end{array}$ & $\begin{array}{l}13 \\
- \\
8 \\
123 \\
155 \\
\frac{38}{6} \\
-\end{array}$ & $\begin{array}{l}11 \\
- \\
34 \\
89 \\
110 \\
1 \\
69 \\
= \\
-\end{array}$ & $\begin{array}{l}11 \\
- \\
30 \\
76 \\
137 \\
\frac{82}{-} \\
-1\end{array}$ \\
\hline Total & 271 & 330 & 340 & 359 & 369 & 295 & 343 & 314 & 337 \\
\hline
\end{tabular}

Total No occupied bed days $=2958$, total No available bed days $=5460$, bed occupancy $=54 \%$.

No of orthopaedic bed days $=1140$ ( $38 \%$ occupied bed days, $20 \%$ available bed days); No of paediatric bed days $=949$ ( $32 \%$ occupied bed days, $17 \%$ available bed days); No of general surgery bed days $=542$ ( $18 \%$ occupied bed days, $10 \%$ available bed days).

there are two cubicles on A ward and occasionally small babies are admitted under the care of the paediatricians there.

(ii) B ward has 19 beds with eight mother and baby cubicles. The majority of the admissions are paediatric medical with some occasional general surgical admissions.

(iii) Children admitted under the care of the neurosurgeons are also admitted onto A or B ward according to their age: with their longer duration of stay, they produce a significant workload and bed occupancy onto these wards. However, there is no planned allocation of beds for their use.

\section{(B) SPECIALTY BED ALLOCATION}

The Körner report made recommendations that included the need to identify the number of beds intended to be used by each specialty and, additionally, to describe how each ward was intended to be used. ${ }^{2}$ This would then allow analysis, by specialty and ward, of the actual bed use compared with what was intended. Particular emphasis in the recommendations was given to analysis of length of stay and throughput per available bed. Throughput was to be calculated '. . . in terms of the number of beds that the specialty was intended to use rather than the beds estimated to be available'. Subsequently the analysis of turnover interval for each specialty was given emphasis.

Both before the Körner recommendations and since their implementation it has been necessary to determine a way of allocating empty beds to specialties. In Yorkshire Regional Health Authority a modified SH3 return has been introduced that identifies for each specialty the available bed days, occupied bed days, and 'finished hospital stays' - a term that encompasses discharges, deaths, and transfers to other hospitals. Bed availability for wards open overnight is to be measured at midnight. There is a need to adapt the number of intended available bed days to allow for unscheduled additional beds or bed borrowing by other specialties to reflect their actual usage.

Bed occupancy is calculated as follows:

$$
\text { Bed occupancy }=\frac{\text { Beds occupied }}{\text { Beds available }} \times 100
$$

Variation will occur in the numerator depend- ing upon when in the 24 hour period it was counted, and in the denominator depending upon whether beds were borrowed from or, alternatively, by, the specialty being analysed.

Under the recommendations of Körner, the specialty allocation of beds should be agreed upon by management within a district as well as identifying the wards in which those beds are placed.

The official way adopted in Wakefield at present for allocating the children's beds on A and B wards in this hospital is: B ward, 19 paediatric beds and A ward, 20 surgical beds.

(c) STATISTICAL ANALYSIS OF BED USAGE The following computer systems were used in the analysis of bed usage.

\section{(i) Patient administration system (PAS)}

PAS was developed by inter-regional collaboration comprising six regional health authorities and the computer company ICL and run on an ICL mainframe. It is a district wide system that keeps track of a patient through his or her stay in hospitals within the district, and produces statistical reports required by the health authority. On PAS additional reports are available that show the number of patients on each ward at midnight on each day during the month by specialty.

\section{(ii) $\mathrm{SH} 3$}

The reference name given to the hospital statistics return in pre-Körner days, it records activity about each specialty in each hospitalthat is, number of allocated beds, average number of available beds, discharges per available bed, etc.

\section{(iii) $Y S H 3 B$}

A manual return to the Yorkshire Regional Health Authority for each hospital site that shows available beds, bed usage, and finished hospital stays.

(iv) ASTRAC

Advisor information system (AIS) runs on an IBM 9370 using IBM application software (AS). 
Extracts of data are taken from the district information system (DIS)-which originates from PAS - to produce standard reports not accessible to the PAS and DIS systems. One of these reports shows bed occupancy by specialty by ward per day. This is different to the SH3 report in that it records all bed episodes which started, ended, or were current during the 24 hour period.

\section{(D) BED USAGE PROBLEMS}

The problem that appeared to be present was that the 19 beds on $B$ ward that were identified as available for paediatrics were not always suitable for a child who was admitted: for example, a 12 year old girl with asthma would be admitted onto A ward, thereby borrowing a bed from a surgical specialty, while leaving several beds unused but 'available' for paediatrics on B ward. Hence the calculation of throughput per bed (or occupancy) for that period would be based upon: the number used +1 and the number available +1 . Thus if there had been 12 patients on B ward before the girl was admitted, the occupancy for paediatrics was $12 / 19(63 \%)$ but when she was admitted onto $A$ ward would be $13 / 20$ (65\%). If, however, an alternative system were used of allocating 19 beds for the paediatric specialty between the 39 children's beds (19 on B ward and 20 on A ward) then the occupancy would be 13/19 $(68 \%)$. The calculation of throughput (discharges per available bed) would similarly be affected in an adverse way for the specialty by being based upon 20 rather than 19 beds. In order therefore to examine this problem a variety of differing ways of analysing the use of beds was identified.

\section{Results (see table 3)}

OPTION 1

The SH3 return equals the number of beds on B ward $(n=19)$ multiplied by the number of days in the quarter, to obtain bed availability. This does not take into account bed borrowing either by surgical specialties of the beds on $B$ ward or by paediatrics of the children's surgical beds on

Table 3 Examples of how different bed availability figures can alter performance indicators in paediatrics

\begin{tabular}{lllr} 
& $\begin{array}{l}\text { Bed } \\
\text { occupancy (\%) }\end{array}$ & Throughput & $\begin{array}{r}\text { Turnover } \\
\text { interval }\end{array}$ \\
\hline Quarter ending & & & \\
December 1988: & & & \\
Option 1 & 89 & 27.84 & 0.37 \\
Option 2 & 80 & 25.09 & 0.75 \\
Option 3 & 91 & 28.35 & 0.31 \\
Option 4 & 84 & 26.15 & 0.59 \\
Option 5 & 106 & 33.10 & -0.17 \\
Quarter ending & & & \\
March 1989: & 80 & 26.26 & 0.73 \\
Option 1 & 73 & 23.83 & 1.10 \\
Option 2 & 91 & 30.02 & 0.27 \\
Option 3 & 76 & 24.97 & 0.91 \\
Option 4 & 106 & 34.68 & -0.16 \\
Option 5 & & & \\
Quarter ending & & 25.84 & 0.93 \\
June 1989: & 75 & 25.67 & 0.96 \\
Option 1 & 74 & 29.81 & 0.44 \\
Option 2 & 87 & 27.07 & 0.76 \\
Option 3 & 79 & 35.43 & -0.08 \\
Option 4 & 103 & & \\
Option 5 & & & \\
\hline
\end{tabular}

A ward. (The data returned over the period of the study upon which health service indicators are based are from option 1.)

\section{OPTION 2}

This takes into account bed borrowing - that is, beds borrowed from $B$ ward by other specialties and unavailable to paediatrics and beds borrowed by paediatrics from $A$ ward and the intensive care unit and others and available to paediatrics. It should be noted that:

(1) From October 1988 to June 1989 beds borrowed by other specialties on B ward (see tables 1 and 2), and therefore unavailable to paediatrics, equalled 777 . (Because this figure is taken from ASTRAC it is inflated as ASTRAC counts any occupancy of a bed during the day whereas PAS only counts those occupied at 12 midnight and identified only 520 of these 777 bed days.)

Beds borrowed by paediatrics from $\mathrm{A}$ ward and therefore available to paediatrics equalled 949 (figure obtained using PAS). Beds in the intensive care unit and other beds also available to paediatrics equalled 201.

(2) The figure borrowed by paediatrics (from other wards and the intensive care unit) was always calculated at $100 \%$ occupancy-for example, revised bed days figure for the period October 1988 to June 1989 equalled 5565, but of this number $1155(20 \%)$ were always calculated at $100 \%$ occupancy.

OPTION 3

This takes option 2 as starting point for bed availability. However, where a bed is on $A$ ward and available to paediatrics and in option 2 is credited to paediatrics, but could be accommodated on B ward at midnight (that is, using PAS) (because there are empty beds on B ward), this figure has been subtracted from the bed availability figure. However, because the PAS figure has been used (that is, bed was vacant at midnight) it could be that it is not always logistically possible to place the patient on B ward.

OPTION 4

This takes option 2 as a starting point for bed availability and as in option 3 where a bed is on A ward and could be on B ward, this figure has been subtracted. However this can only be done when it is logistically certain to be possible-that is, when the ASTRAC figure for B ward allows it.

OPTION 5

This identifies all 39 children's beds as a total between A and B wards. Of these 39 beds, 19 nominally are allocated to paediatrics, the remainder to the surgical specialties. Borrowing thereby only occurs when paediatric admissions exceed 19 in total whether they are accommodated on A or B ward. This requires a nominal number of beds to be allocated from the 39 to general surgery, orthopaedics, and urology. When they are vacant and thereby 
unused by the surgical specialty, the usage is analysed according to the nominal allocation to each of those specialties - that is, surgical 11, orthopaedics 7, and urology 2 .

\section{Discussion}

The results displayed in table 3 indicate how variable the bed occupancy and throughput can be, for the same number of patients with the same length of stay, according to the method used for analysing the bed usage for the specialty of paediatrics. Bed occupancy ranges from $73 \%$ to $106 \%$ and the throughput ranges from 23.83 to 35.43 discharges per bed/day. A figure of more than $100 \%$ occupancy could be derived as more than one patient may occupy a bed in a given day.

Separate analysis of the bed utilisation of the surgical specialties has not at this stage been done. All of the beds identified for the use of paediatrics will be on a children's unit. When children are taken to intensive care, the bed is borrowed. In the surgical specialties, however, only a proportion of the total specialty allocation of beds will be those on the children's ward, but all children treated by those specialties should be on a children's unit. ${ }^{3-6}$ Analysis of their utilisation on the children's ward therefore will be diluted by the larger numbers of the surgical specialty beds elsewhere. Nevertheless, it seems desirable to attempt to analyse children's bed usage all together.

For the specialty of paediatrics, analysis of bed utilisation within a district will need to be done using a standardised method which is fair to the specialty. Furthermore, if districts are to be compared with each other and if costs are based upon the way in which beds are used, it is essential that each district adopt the same method of analysing beds. The most reasonable way of allocating beds appears to be option 5 detailed above, and that seems to be more in the spirit of Körner than the other options. The question of how the surgical specialties use of beds within the children's unit would best be analysed has been left unanswered.

1 Department of Health and Social Security. DHSS health building note 23: hospital accommodation for childrent.

2 Körner E, chairman. NHS/DHSS Steering Group on Health Services Information. First to sixth reports, 1982 to 1984 London: HMSO. (Körner reports.)

3 Thornes R. Where are the children? Caring for children in the health service. Joint report from the working party of the British Paediatric Association, National Association for the Welfare of Children in Hospital, National Association of Health Authorities, and the Royal College of Nursing, 1987. (Available from the BPA, London.)

4 British Paediatric Association. BPA response to Department of Health draft circular 'Welfare of children in hospital'. London: BPA, 1988

5 British Paediatric Association. Response to the government's white paper Working for patients. London: BPA, 1989.

white paper Working for patients. London: BPA, 1989. HMSO, 1959. 